\title{
Una Dolorosa del eSCUltor SEVILlano CRISTÓbal Ramos
}

\section{"A Sorrowful Virgin by the Sevillian sculptor Cristóbal Ramos"}

\section{René Jesús Payo Hernanz ${ }^{1}$}

Recibido: 2-5-2020

Aceptado: 8-7-2020

\section{Resumen}

En la iglesia de Buniel (Burgos), se conserva una interesante escultura de la Virgen Dolorosa, ejecutada en barro y en telas encoladas en los años finales del siglo XVIII. Esta escultura, por sus características no responde a los modelos de los escultores castellanos de finales del siglo XVIII. Una vez realizado el estudio de la misma estamos en condiciones de señalar que fue ejecutada por el escultor sevillano Cristóbal Ramos (1725-1799).

Palabras clave: Cristóbal Ramos, escultura de la Dolorosa, Buniel, Burgos, Sevilla, escultura de finales del siglo XVIII.

\section{Abstract}

In the church of Buniel (Burgos), there is an interesting sculpture of the Virgin of Sorrows, made of clay and glued cloth in the late 18th century. This sculpture, due to its characteristics, does not correspond to the model sof the Castilian sculptors of the end of the 18th century. Once the study of the same we are able to point out that it was executed by the Sevillian sculptor Cristóbal Ramos (1725-1799).

Keywords: Cristóbal Ramos, sculpture of la Dolorosa, Buniel, Burgos, Seville, late 18th century sculpture. 


\section{Cristóbal Ramos, un escultor polifacético}

El conocimiento de la vida y obra del escultor Cristóbal Ramos (1725-1799) se ha ampliado significativamente en los últimos años. Desde que Carmen Montesinos escribiera su monografía sobre este singular artista, muchas han sido las aportaciones que nos permiten tener hoy una buena visión de lo que significó en la historia de la escultura tardodieciochesca sevillana y de la dispersión de sus trabajos $^{2}$.

Fue una de las figuras más interesantes de la imaginería tardobarroca hispalense. Este maestro desarrolló su vida profesional en un contexto en el que la potente inercia barroca, que con tanta fuerza se había mantenido en la primera mitad del siglo XVIII, comenzaba a matizarse girando hacia planteamientos algo más contenidos y clasicistas, teñidos en muchos casos de caracteres rococós ${ }^{3}$. Nacido en 1725, fue hijo del también maestro de escultura Juan Isidoro Ramos, del que no se tienen muchos datos, aunque a través de las noticias conocidas sabemos que desarrolló una actividad polifacética en la que tuvo una especial importancia la ejecución de elementos de barro vidriado ${ }^{4}$.

Cristóbal Ramos, uno de sus hermanos, llamado Antonio, y su padre estuvieron involucrados en algunos singulares proyectos ilustrados como la instalación de un teatro de ópera en Sevilla en 1760, aunque esta iniciativa no funcionó y arruinó a la familia, situación que les llevó a establecer un puesto ambulante de venta de objetos (muñecos y juguetes) de barro ${ }^{5}$.

En la década de los años 70 del siglo XVIII, Cristóbal Ramos estuvo involucrado en otro gran proyecto ilustrado: la creación de la Escuela de las Tres Nobles Artes, de la que fue teniente de escultura colaborando con Blas Molner. En los últimos 25 años de su vida compaginó de manera muy fructífera las labores docentes, siendo uno de los más importantes formadores de la nueva generación de escultores que iniciaron la plástica neoclásica en la ciudad, entre los que destaca Juan de Astorga, con la realización de una amplia labor como autor de múltiples imágenes ligadas a las devociones populares sevillanas ${ }^{6}$.

Creemos que su formación debió de producirse en el taller de su padre que, como dijimos, trabajó esencialmente el mundo del barro. Obviamente, además del aprendizaje en el taller familiar, el escultor debió de estar muy atento a la amplísima nómina de grandes maestros que en los años centrales del siglo XVIII laboraban en la capital hispalense todavía dentro de una plena tradición barroquista.

El estilo de Ramos camina desde planteamientos barrocos, ligados a la estética graciosista de escultoras como La Roldana, con un cierto gusto por lo amuñecado, que desembocan en formas de carácter rococó, culminando en una cierta tendencia clasicista. Sus trabajos muestran todavía una clara vocación por el movimiento, por las composiciones diagonales y por el uso nervioso del plegado de

2 MONTESINOS MONTESINOS, C. El escultor sevillano D. Cristóbal Ramos (1725-1799). Sevilla: Excma. Diputación Provincial de Sevilla, 1986.

3 RODA PEÑA, J. Escultura en la Baja Andalucía durante el siglo XVIII: síntesis interpretativa e historiografía reciente. Mirabilia Ars, 2014, n' 1 , pp. 162-218.

4 Sabemos que colaboró en la realización de los adornos de barro vidriado de la fachada de la capilla sacramental de Santa Catalina (MONTESINOS MONTESINOS. ref. 2, p. 15).

5 MONTESINOS MONTESINOS. ref. 2, pp. 18-19.

6 MONTESINOS MONTESINOS. ref. 2, pp. 20-23. 
paños. Los rostros de sus imágenes son capaces de transmitir sentimientos de dulzura o dolor, aunque presentan unos caracteres contenidos ${ }^{7}$.

Ramos desarrolló, siguiendo la tradición paterna, buena parte de su actividad productiva en el ámbito del barro. Dentro de su catálogo, una parte significativa de sus obras son terracotas, siendo muchos de sus trabajos un magnífico ejemplo de «escultura polimatérica» ${ }^{8}$, ya que es muy frecuente la mezcla de distintos materiales en una misma escultura, siendo habitual en sus producciones el uso de las telas encoladas, la madera como bastidor, la pasta de madera, etc ${ }^{9}$. Hay que señalar que una parte esencial en sus trabajos fueron las policromías que, casi con toda seguridad, fueron realizadas por el propio maestro escultor, dando lugar a producciones integrales y homogéneas, aunque se ha señalado que quizá alguno de sus oficiales pudo estar especializado en este campo. Empleó encarnaduras mates, con tonos nacarados en las figuras femeninas e infantiles, encontrándose un poco más entonadas hacia el ocre oscuro las de las imágenes masculinas. En los ropajes, cuando no se trata de imágenes vestideras, usa una rica paleta de colores, siendo frecuentes los estofados, empleando el yeso para generar relieves sobre todo en las cenefas. Fueron frecuentes los elementos postizos en muchas de sus creaciones siendo habitual el uso de ojos de cristal y dientes de marfil ${ }^{10}$.

En relación a los tipos iconográficos desarrollados por Ramos, hemos de señalar que su producción fue esencialmente religiosa, siendo el cabildo sevillano ${ }^{11}$, las iglesias, cofradías y hermandades quienes reclamaron buena parte de sus trabajos, aunque también hizo muchas obras para clientes individuales. Dentro de las producciones de este maestro destacaron las imágenes de santos, entre las que sobresalen las josefinas ${ }^{12}$, de Cristo representado en nacimientos, en su infancia o como Buen Pastor y casi siempre dotado de unos evidentes toques de dulzura.

Pero fue, sobre todo, en las imágenes marianas en distintas advocaciones y misterios ${ }^{13}$ donde más destacó este escultor, desarrollando una amplia serie de obras en las que las representaciones de las dolorosas tendrán un gran protagonismo ${ }^{14}$, habiendo sido muy celebradas algunas de sus tallas procesionales con esta devoción ${ }^{15}$. Dentro de la iconografía de la Dolorosa ligada a la producción de Ramos, destacan aquellas piezas que no tuvieron fines procesionales, sino de culto exclusivamente interno. Se trata de esculturas genuflexas, dotadas de una enorme fuerza emocional y de grandes capacidades

7 MONTESINOS MONTESINOS. ref. 2, pp. 27-29.

8 En los últimos años están desarrollándose, tanto en España como en otros territorios europeos, interesantes estudios sobre la escultura polimatérica (VARIOS AUTORES. Escultura ligera. Valencia: Ajuntament de Valencia, 2017; CASCIARO, R. Cartapesta e scultura polimaterica. Lecce: Mario Congedo Editore, 2012).

9 PORRES BENAVIDES, J. La técnica en el escultor Cristóbal Ramos (1715-1799). Ucoarte. Revista de Teoría e Historia del Arte. 2019, no 8, pp. 95-108.

10 MONTESINOS MONTESINOS. ref. 2, pp. 30-31.

11 RECIO MIR, A. El escultor Cristóbal Ramos al servicio del Cabildo de la Catedral de Sevilla. Boletín de Bellas Artes, 2001, n² 29 , pp. 153-159.

12 RODA PEÑA, J. Esculturas de Cristóbal Ramos en la Capilla de San José de Sevilla. Laboratorio de Arte, 2018, nº 30, pp. $303-318$.

13 En su producción tuvo una gran importancia la iconografía de la Virgen del Rosario (RAMOS SUÁREZ, M. A. El escultor Cristóbal Ramos y la iconografía rosariana en Sevilla. Boletín de las Cofradias de Sevilla, 2005, no 559, pp. 616-619).

14 MONTESINOS MONTESINOS. ref. 2, pp. 31-34.

15 Destaca la Dolorosa de candelero de las Aguas labrada en 1772, titular de la cofradía del Museo de Sevilla (MONTESINOS MONTESINOS. ref. 2, pp. 43-44). 
devocionales. Este tipo escultórico tiene sus raíces representativas más lejanas en la imagen de la Soledad del Convento de los Mínimos de la Victoria de Madrid, labrada por Gaspar Becerra en 1565, encargada por Isabel de Valois y vestida con las ropas de la condesa viuda de Ureña, que tuvo una gran repercusión en la iconografía mariana del Barroco, ya que fue objeto de enorme difusión a través de copias pictóricas y grabados y también de trasuntos escultóricos que en muchos casos fueron identificados con la devoción a la Dolorosa ${ }^{16}$. En este sentido, algunos artistas como José de Mora contribuyeron poderosamente a la difusión de este tipo iconográfico en Andalucía a través de algunas piezas como la que labró para el Oratorio de San Felipe Neri de Granada en $1671^{17}$. La influencia que tuvo esta imagen llegó a Sevilla, donde una de estas representaciones fue titular del Oratorio de San Felipe Neri de esa ciudad, que estaba bajo el patro-

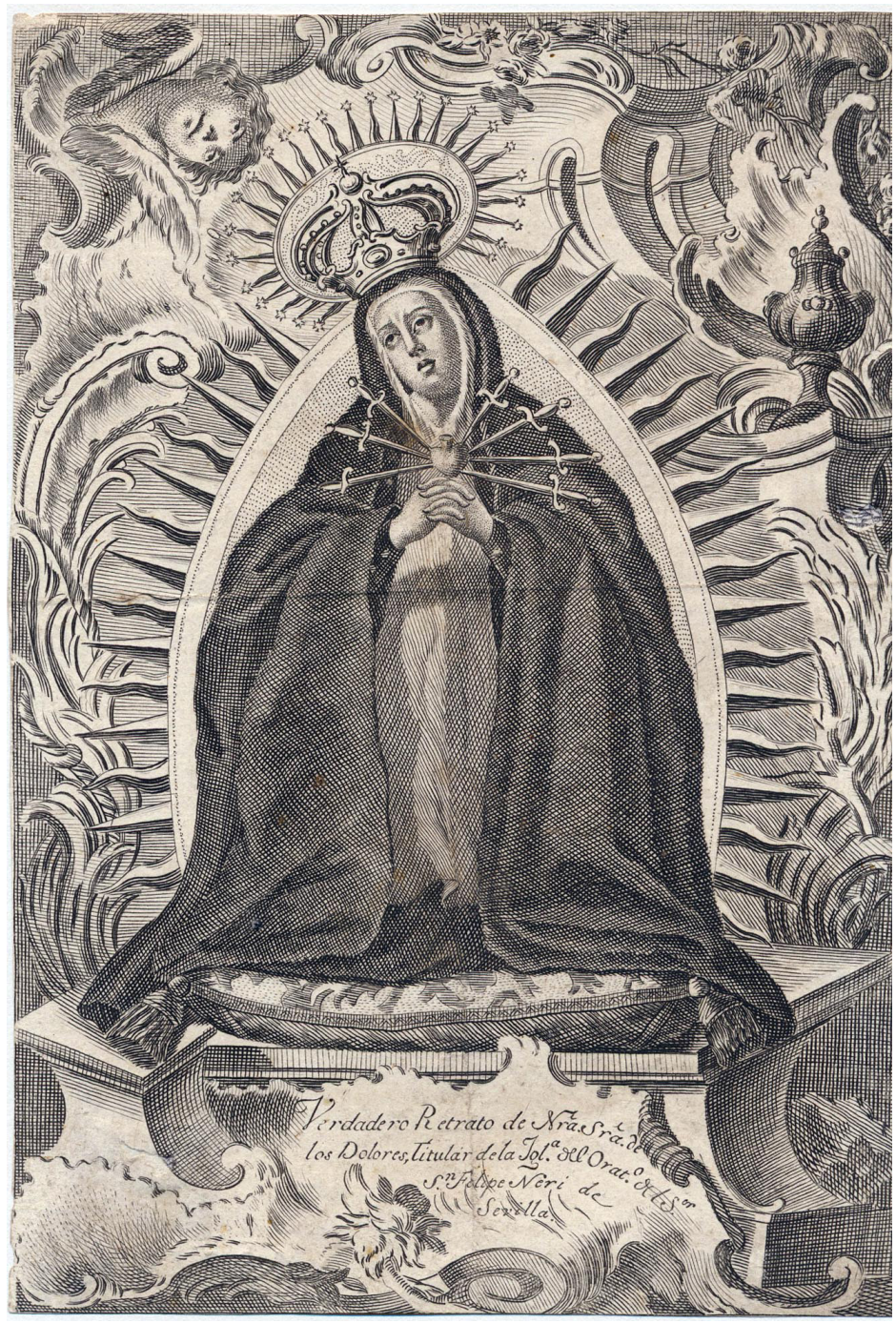

Fig. I: Grabado de fines del siglo XVIII de la Dolorosa del Oratorio de San Felipe Neri de Sevilla.

cinio de Nuestra Señora de los Dolores y que fue fundado a finales del siglo XVII por los padres oratorianos granadinos ${ }^{18}$. Esta obra no se ha conservado en su emplazamiento original, ya que fue trasladada a la iglesia de San Alberto de Sevilla, habiendo sido asignada al entorno de Pedro Roldán, escultor que desarrolló el modelo de Dolorosa genuflexa en algunas otras ocasiones anteriores ${ }^{19}$. La imagen titular del Oratorio sevillano era, en origen, una talla completa que se convirtió a finales del

16 ROMERO TORRRES, J. L. La condesa de Ureña y la iconografía de la Virgen de la Soledad de los frailes mínimos (I y II). Cuadernos de los Amigos de los Museos de Osuna, 2012 y 2013, nº14 y 15, pp. 55-62 y 90-98; ARIAS MARTÍNEZ, M. La copia más sagrada»: la escultura vestidera de la Virgen de la Soledad de Gaspar Becerra y la presencia del artista en el convento de Mínimos de la Victoria de Madrid, Boletín de la Real Academia de Bellas Artes de la Purísima Concepción, 2011, no 46, 2011, pp. 33-56. ARIAS MARTÍNEZ, M. Vestida de luto y simulacro sagrado: la Virgen de la Soledad de la Victoria de Madrid y la importancia de su atuendo. En Statue Vestite. Prospettive di ricerca. Pisa: University Press, 2017, pp. 103-116.

17 DÍAZ GÓMEZ, J. A. Un templo para Nuestra Señora de los Dolores. La Congregación del Oratorio de San Felipe Neri de Granada y su papel como difusora de un tipo iconográfico de la Mater Dolorosa en Andalucía. En: Virgo Dolorosa. Actas del Congreso Internacional "Virgo Dolorosa". Carmona: Fraternidad de la B.V. María Dolorosa, 2015, pp. 533-546.

18 ESPINOSA y CARCEL, A. M. Anales Eclesiásticos y Seculares de la Muy Noble y Muy Más Leal Ciudad de Sevilla, T. V. Madrid: Imprenta Real. 1796. pp. 452-558; MARTÍN RIEGO, M. y RODA PEÑA, J. El Oratorio de San Felipe Neri de Sevilla. Historia y Patrimonio Artístico. Córdoba: Cajasur, 2004.

19 RODA PEÑA, J. Pedro Roldán, escultor 1624-1699. Madrid: Arco/Libros, S.L., 2012; GARCÍA LUQUE, M. Pedro Roldán y la escultura sevillana del último Seiscientos: reflexiones en torno a un Calvario disperso. Cuadernos de arte de la Universidad de Granada, 2012, nº 43, pp. 75-94. 
siglo XVIII, siguiendo los usos del momento, en una talla de vestir que conocemos en su configuración tardobarroca a través de un grabado (Fig. 1). No descartamos que fuera uno de los referentes de Cristóbal Ramos para desarrollar sus dolorosas arrodilladas.

Aunque es cierto que lo más granado de la actividad de Ramos estuvo ligado al mundo religioso, en algunas ocasiones también desarrolló obras de tipo civil, vinculadas al campo de la retratística, tal y como se evidencia en el retrato escultórico en busto del canónigo sevillano Francisco del Río, conservado en la iglesia de San Mateo de Jerez de la Frontera fechado en $1748^{20}$, y en el retrato sedente de Gaspar Melchor de Jovellanos que actualmente se conserva en el Museo Casa Natal de Jovellanos como depósito del Museo Nacional de Artes Decorativas ${ }^{21}$.

\section{La Dolorosa de Buniel (Burgos) en el contexto de las dolorosas de Cristóbal Ramos}

En la iglesia parroquial de Buniel (Burgos) se conserva una interesante imagen de la Dolorosa (74 x 53 x $38 \mathrm{~cm})$ asignable, con toda seguridad, a Cristóbal Ramos, ejecutada en los últimos lustros del siglo XVIII. No parece que haya tenido ni mutilaciones ni grandes transformaciones desde esos momentos, manteniendo perfectamente los rasgos originales. No hay noticias documentales que clarifiquen cómo se produjo la llegada de esta pieza. No sabemos si pudo llegar, al poco de su ejecución, o si por el contrario su ingreso en el templo tuvo lugar en momentos muy posteriores. Lo cierto es que en la localidad no hay noticia de que la imagen llegara como donación, en tiempos recientes y la memoria local señala que ha tenido un culto muy arraigado en la población desde antiguo ligado esencialmente a los momentos de la Semana Santa. Quizá se trate de una donación particular y sus dimensiones hacen pensar que acaso estuvo vinculada, en origen, a un culto en un oratorio privado.

Se trata de una escultura en la que la Virgen se halla arrodillada sobre un cojín rojo decorado con una cenefa dorada. Viste túnica marrón, ornada con motivos vegetales de caracteres rococós dorados (Fig. 2). Cubre su cabeza y parte de su cuerpo con una toca blanca igualmente ribeteada en oro. Un gran manto azul, con ribetes y elementos decorativos vegetales dorados se sitúa sobre su cabeza, hombros y espalda. Este manto solamente aparece trabajado en la zona visible quedando en la parte trasera sin decorar, lo que evidencia que esta imagen estuvo pensada para ser observada frontalmente. Los brazos se encuentran ligeramente extendidos hacia adelante y lleva las manos abiertas. La cabeza está ligeramente inclinada, mirando hacia las manos, dando la sensación de que en ellas portó algún elemento de carácter pasional, aunque quizá lo que haya querido representar el escultor sea la desolación de María en el mismo momento de la muerte de Cristo con una pose un tanto teatral. Resulta este un elemento singular, en la obra de Ramos, pues sus dolorosas genuflexas presentan sus manos juntas en actitud de oración.

20 MORENO ARANA. J. M. Tres nuevas obras del escultor Cristóbal Ramos. Laboratorio de Arte, 2017, n 29 , p. 824.

21 Se trata de un encargo que se hizo a este profesional por Jovellanos cuando fue nombrado Alcalde del Crimen en 1770. MARTíNEZ LARA, P. M. y TORRE AMERIGHI, I. de la. Una escultura desconocida de Cristóbal Ramos (1725-1799). Iconografía, uso artístico y mentalidad ilustrada a propósito de una imagen de San José con el Niño, Liño. Revista Anual de Historia del Arte, 2017, nº 23, p. 63; SÁNCHEZ DE LOS REYES, F. J. La Virgen de las Aguas... ¿ en Valladolid? Una imagen atribuida a Cristóbal Ramos en el Museo Nacional de Escultura. Boletín de las Cofradías de Sevilla. Sevilla, 2003, n 533, pp. 498-499. 


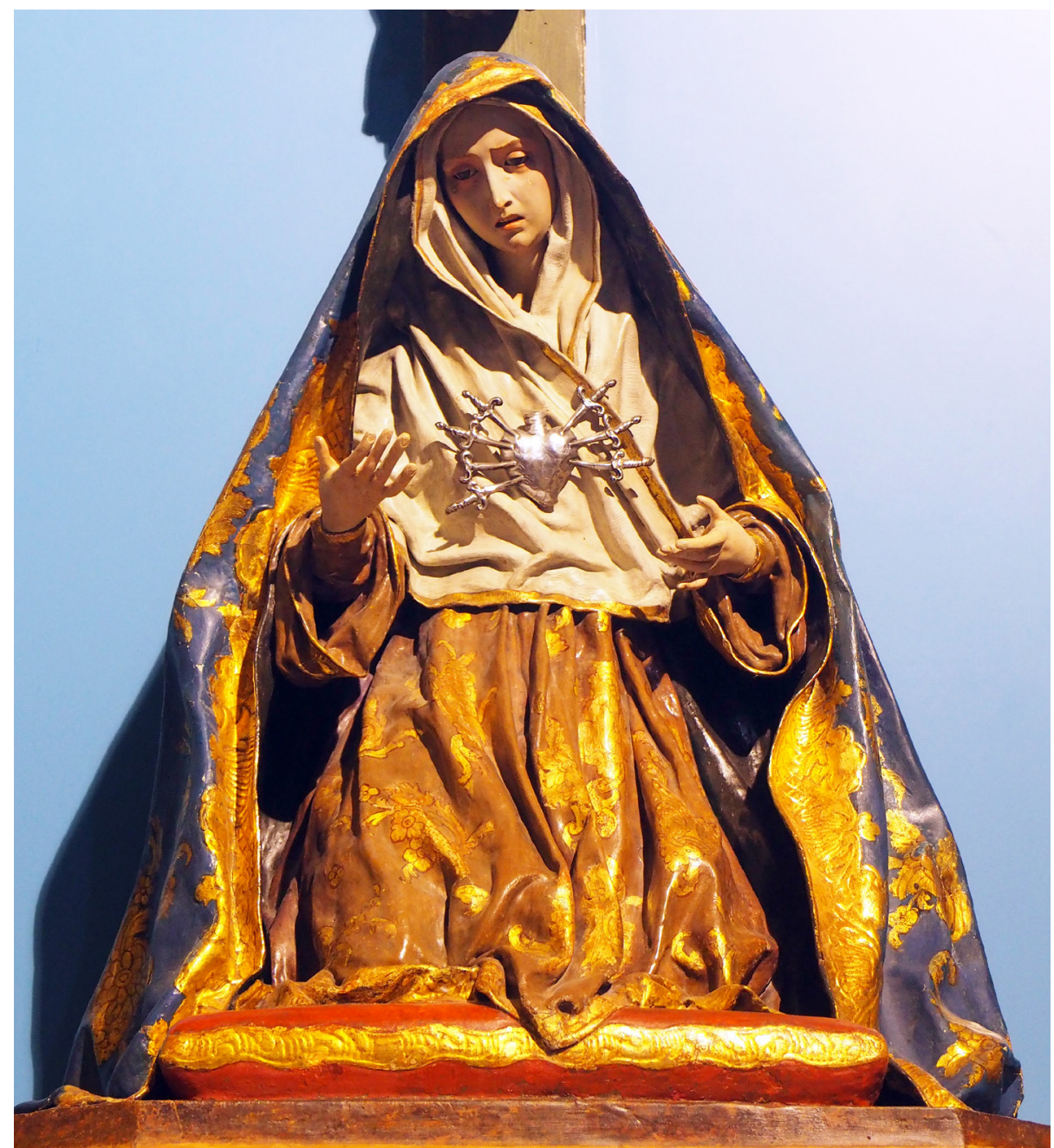

Fig. 2: Dolorosa. Cristóbal Ramos. Iglesia parroquial de Buniel (Burgos).

Esta escultura pudo estar pensada para ubicarse a los pies de un crucificado, que no se ha conservado, como ocurre con la Dolorosa de la iglesia de Soto de Cameros (La Rioja) atribuida a este escultor ${ }^{22}$. También pudo haberse pensado como una devoción individual. El rostro presenta logradísimas calidades a las que contribuye la esmerada policromía nacarada. Con boca entreabierta que deja ver la dentadura ejecutada en marfil y ojos de cristal de los que se desprenden lágrimas, esta obra muestra unos caracteres de contenido dramatismo (Fig. 3). La faz de la Virgen recuerda a la de una Dolorosa de Ramos, fechada y documentada en 1752, que originariamente fue titular de la Cofradía del Silencio de Sevilla, una imagen de candelero para vestir, que desde mediados de la década de 1950 se halla en una colección particular

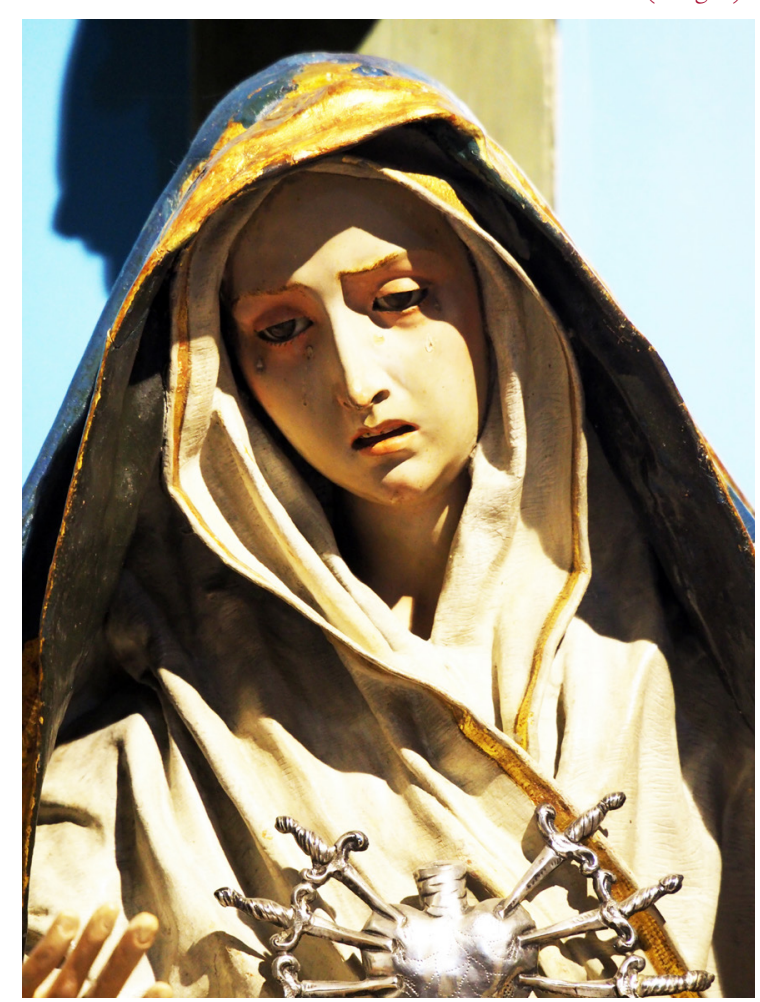

22 LABARGA, F. Varias obras atribuibles al escultor sevillano Cristóbal Ramos en La Rioja. Archivo Español de Arte, 2019, n 368, pp. 435-442. 


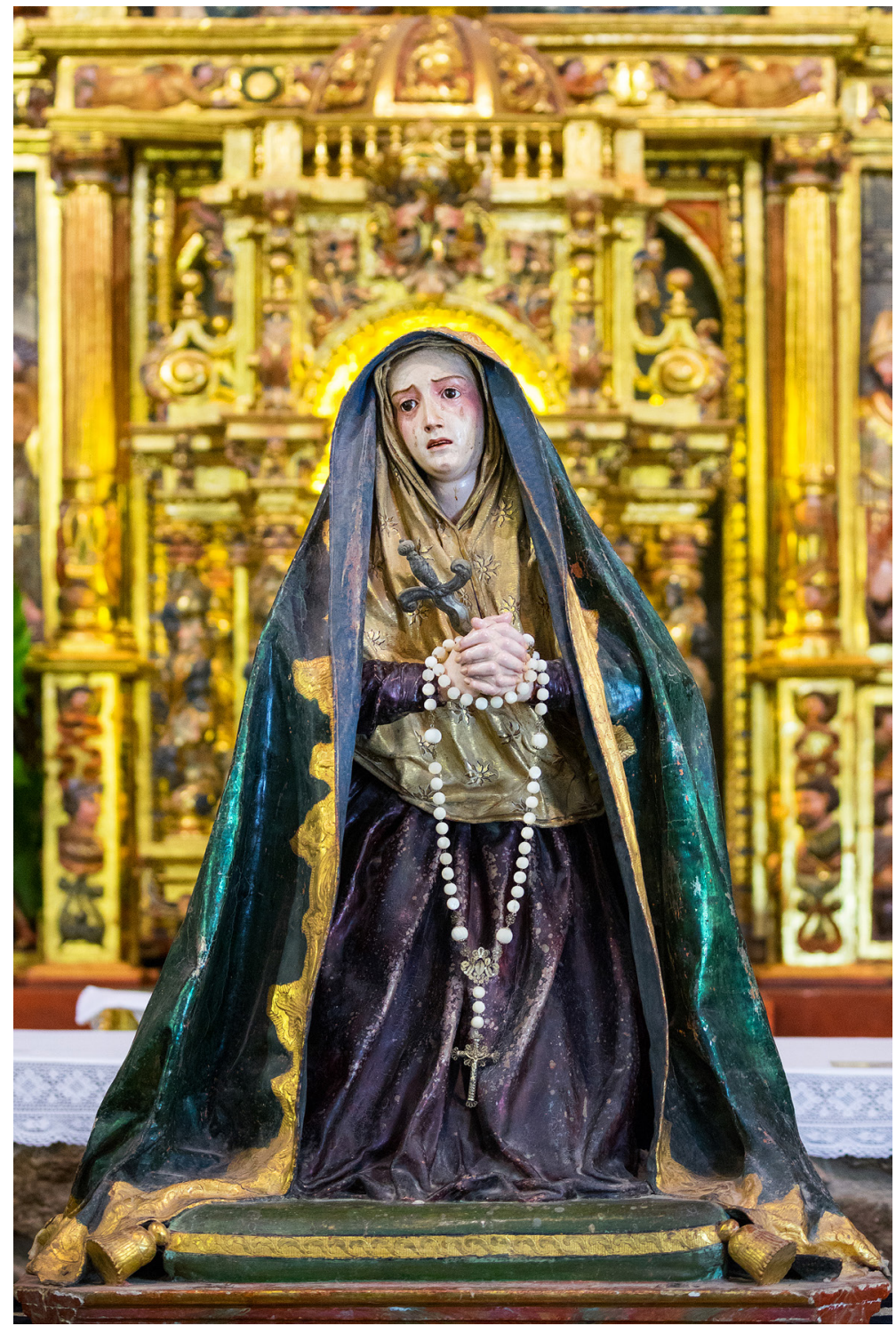

Fig. 4: Dolorosa. Cristóbal Ramos. Iglesia parroquial de Ajamil (La Rioja). Foto Jaime Ocón Paillao. sevillana, convertida en una efigie de busto prolongado, revestida de telas encoladas ${ }^{23}$.Destaca como elemento adventicio un corazón de plata con siete cuchillos representativos de los Siete Dolores.

Aunque no hemos hallado documentación ni firma en esta imagen, no nos cabe ninguna duda de que fue realizada por Cristóbal Ramos. En primer lugar, las técnicas y los materiales coinciden con los usados por este escultor. Así se tallaron en barro rostro y manos y se emplearon telas encoladas para las vestimentas. Tipológicamente, la Dolorosa de Buniel aparece vinculada a algunas otras imágenes del maestro. Así, guarda notables paralelismos con la imagen de la Dolorosa de Ajamil (La Rioja) que llegó a esa localidad, gracias a la donación que hizo el comerciante riojano asentado en Sevilla José Francisco de Llera Íñiguez (Fig. 4) o a la de Soto de Cameros (La Rioja) donde llegó merced a la intervención

de Juan José Pablo Fernández, que tuvo un notable protagonismo en la Escuela de Cristo de Sevilla y que mantuvo notables relaciones con este escultor ${ }^{24}$. En los tres casos, las imágenes se encuentran arrodilladas sobre cojines y las poses muestran también bastantes paralelismos, aunque las piezas riojanas tienen las manos juntas y su policromía resulta algo más sencilla. Igualmente existen algunas diferencias en el tratamiento del rostro ya que en las esculturas de La Rioja la Virgen tiene la mirada alzada, al contrario de lo que ocurre con la burgalesa ${ }^{25}$.

Estos ejemplares riojanos y el burgalés presentan evidentes semejanzas con la imagen conservada en la Escuela de Cristo de Sevilla (conocida como Consolatrix Afflictorum) ejecutada por Ramos en 1798 (Fig. 5) y con la que también está íntimamente relacionada la del Colegio de Nuestra Señora

23 RODA PEÑA, J. La Inmaculada Concepción y la Hermandad del Silencio de Sevilla. Manifestaciones artísticas entre los siglos XVII al XX. En: José RODA PEÑA, editor. V Simposio sobre Hermandades de Sevilla y su provincia. Sevilla, 2004, pp. $235-270$.

24 LABARGA, F. ref. 22, pp. 435-442.

25 En la iglesia de Soto de Cameros, existe otra escultura de la Dolorosa que, con menor calidad, puede tener origen sevillano ligado al entorno de Cristóbal Ramos (LABARGA, F. ref. 22, p. 441). 


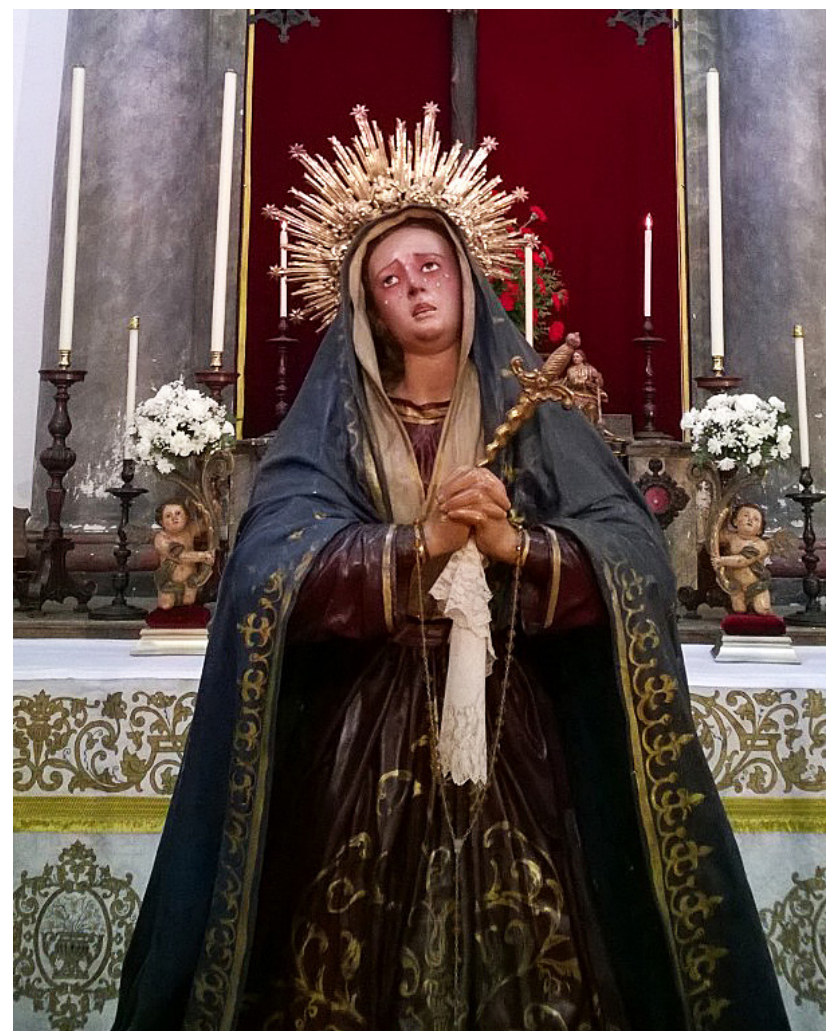

Fig. 5: Dolorosa Consolatrix Afflictorum. Cristóbal Ramos. Escuela de Cristo de Sevilla.

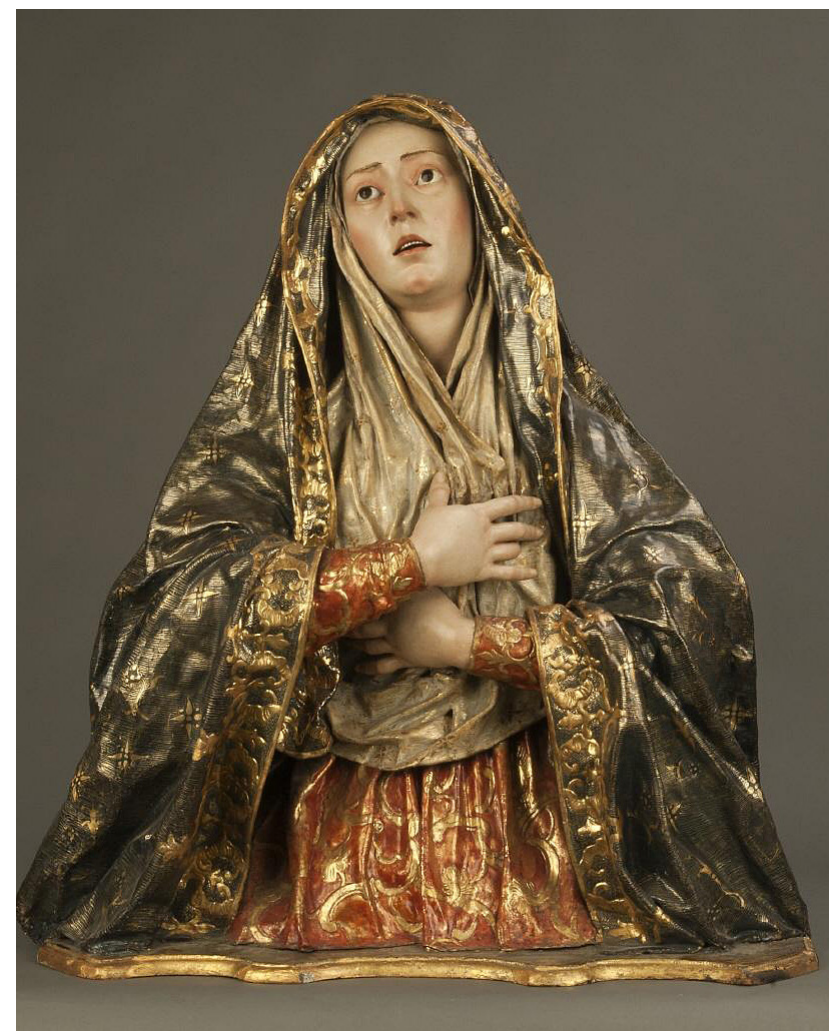

Fig. 6: Dolorosa. Cristóbal Ramos. Valladolid, Museo Nacional de Escultura.

del Rosario de Jerez de la Frontera (Cádiz), atribuida al maestro, aunque en este caso, como en los riojanos, la faz de la Virgen se halla alzada, mirando hacia arriba lo que, en origen, parece que la ponía en relación con la imagen de un $\mathrm{Cristo}^{26}$. Aún podemos señalar otras piezas ligadas a Ramos que mantienen, con ligeras variantes, este modelo de Dolorosa, tal y como ocurre en la que aparece en el retablo del santo Cristo de la capilla del Palacio de San Telmo de Sevilla. Igualmente, la escultura de Buniel está en relación con el busto de la Dolorosa que se conserva en el Museo Nacional de Escultura asignado al maestro sevillano (Fig. 6). Tanto el tratamiento de los paños, como la policromía y las técnicas utilizadas la relacionan con la escultura de Burgos, aunque la vallisoletana es un modelo de medio cuerpo, ligado probablemente al culto doméstico o conventual ${ }^{27}$.

26 MORENO ARANA. J. M.: ref. 20, p. 826.

27 ARIAS MARTÍNEZ, M. y LUNA MORENO, L. Museo Nacional de Escultura. Madrid: Ministerio de Cultura, 1995, pp. 83-84; MARCOS VILLÁN, M. Á. Virgen Dolorosa. En: ARIAS MARTÍNEZ, comisario. Cuerpos de dolor: la imagen de lo sagrado en la escultura española (1500-1750). Sevilla; Consejería de Cultura de Andalucía, 2012. pp. 96-97. 


\section{Bibliografía}

ARIAS MARTÍNEZ, Manuel y LUNA MORENO, Luis. Museo Nacional de Escultura. Madrid: Ministerio de Cultura, 1995, pp. 83-84. ISBN 10: 8489162603.

ARIAS MARTÍNEZ, Manuel. La copia más sagrada»: la escultura vestidera de la Virgen de la Soledad de Gaspar Becerra y la presencia del artista en el convento de Mínimos de la Victoria de Madrid, Boletín de la Real Academia de Bellas Artes de la Purísima Concepción, 2011, n 46, 2011, pp. 33-56. ISSN: 1132-0788.

ARIAS MARTÍNEZ, Manuel. Vestida de luto y simulacro sagrado: la Virgen de la Soledad de la Victoria de Madrid y la importancia de su atuendo. En: Statue Vestite. Prospettive di ricerca. Pisa: University Press, 2017, pp. 103-116. ISBN 978-88-6741-720-9.

CASCIARO, Raffaele. Cartapesta e scultura polimaterica. Lecce: Mario Congedo Editore, 2012. ISBN 9788880869849.

DÍAZ GÓMEZ, José Antonio. Un templo para Nuestra Señora de los Dolores. La Congregación del Oratorio de San Felipe Neri de Granada y su papel como difusora de un tipo iconográfico de la Mater Dolorosa en Andalucía. En: Virgo Dolorosa. Actas del Congreso Internacional “Virgo Dolorosa”. Carmona: Fraternidad de la B.V. María Dolorosa, 2015, pp. 533-546. ISSN 978-84-608-3586-8.

ESPINOSA y CARCEL, Antonio María. Anales Eclesiásticos y Seculares de la Muy Noble y Muy Más Leal Ciudad de Sevilla, T. V. Madrid: Imprenta Real. 1796.

GARCÍA LUQUE, Manuel. Pedro Roldán y la escultura sevillana del último Seiscientos: reflexiones en torno a un Calvario disperso. Cuadernos de arte de la Universidad de Granada, 2012, nº 43, pp. 75-94. ISSN 0210-962X.

LABARGA, Fermín. Varias obras atribuibles al escultor sevillano Cristóbal Ramos en La Rioja. Archivo Español de Arte, 2019, nº 368, pp. 435-442. ISSN 0004-0428.

MARCOS VILLÁN, Miguel Ángel. Virgen Dolorosa. En Manuel ARIAS MARTÍNEZ, comisario. Cuerpos de dolor: la imagen de lo sagrado en la escultura española (1500-1750). Sevilla; Consejería de Cultura de Andalucía, 2012. pp. 9697, ISBN 10: 8499591086.

MARTÍN RIEGO, Manuel y RODA PEÑA, José. El Oratorio de San Felipe Neri de Sevilla. Historia y Patrimonio Artístico. Córdoba: Cajasur, 2004. ISBN: 84-7959-539-6.

MARTÍNEZ LARA, Pedro Manuel y TORRE AMERIGHI, Iván de la. Una escultura desconocida de Cristóbal Ramos (1725-1799). Iconografía, uso artístico y mentalidad ilustrada a propósito de una imagen de San José con el Niño, Liño. Revista Anual de Historia del Arte, 2017, n² 23, pp. 57-68. ISSN-e 2341-1139.

MONTESINOS MONTESINOS, Carmen. El escultor sevillano D. Cristóbal Ramos (1725-1799). Sevilla: Excma. Diputación Provincial de Sevilla, 1986. ISBN 13: 9788450533071.

MORENO ARANA. José Manuel. Tres nuevas obras del escultor Cristóbal Ramos. Laboratorio de Arte, 2017, nº 29, pp. 819-826. ISSN 1130-5762. 
PORRES BENAVIDES, Jesús. La técnica en el escultor Cristóbal Ramos (1715-1799), Ucoarte. Revista de Teoría e Historia del Arte. 2019, nº 8, pp. 95-108. ISSN-e 2255-1905.

RECIO MIR, Álvaro. El escultor Cristóbal Ramos al servicio del Cabildo de la Catedral de Sevilla. Boletín de Bellas Artes, 2001, nº 29, pp. 153-159. ISSN 0210-6531.

RODA PEÑA, José. La Inmaculada Concepción y la Hermandad del Silencio de Sevilla. Manifestaciones artísticas entre los siglos XVII al XX. En: José RODA PEÑA, editor. V Simposio sobre Hermandades de Sevilla y su provincia. Sevilla, 2004, pp. 235-270. ISBN: 84-8093-134-5.

RODA PEÑA, José. Pedro Roldán, escultor 1624-1699. Madrid: Arco/Libros, S.L., 2012. ISBN 978-84-7635-846-7.

RODA PEÑA, José, “Escultura en la Baja Andalucía durante el siglo XVIII: síntesis interpretativa e historiografía reciente”. Mirabilia Ars, 2014, nº 1, pp. 162-218. ISSN 1676-5818 126.

RODA PEÑA, José. Esculturas de Cristóbal Ramos en la Capilla de San José de Sevilla. Laboratorio de Arte, 2018, ${ }^{\circ}$ 30, pp. 303-318. ISSN 1130-5762.

ROMERO TORRES, José Luis. La condesa de Ureña y la iconografía de la Virgen de la Soledad de los frailes mínimos (I y II). Cuadernos de los Amigos de los Museos de Osuna, 2012 y 2013, nº14 y 15, pp. 55-62 y 90-98. ISSN: 1697-1019.

SÁNCHEZ DE LOS REYES, Francisco Javier. La Virgen de las Aguas... ¿en Valladolid? Una imagen atribuida a Cristóbal Ramos en el Museo Nacional de Escultura. Boletín de las Cofradías de Sevilla. Sevilla, 2003, nº 533, pp. 498-499. ISSN 1137-2893.

VARIOS AUTORES. Escultura ligera. Valencia: Ajuntament de Valencia, 2017. ISBN 978-84-9089-056-1. 